\title{
EFFICIENCY AND DETERMINANTS ANALYSIS OF CHINESE INFRASTRUCTURE PPP PROJECTS IN THE CONSTRUCTION AND OPERATION STAGES
}

\author{
LiPing XU, Ning LIU D *, ShuXia ZHANG, HuangJing QIU, Li CHEN, Zeyu WANG \\ Department of Accounting, Business School, Hunan University, Changsha 410082, China
}

Received 30 May 2018; accepted 16 November 2018

\begin{abstract}
Public-private partnerships (PPPs) are used for infrastructure projects, but they usually involve risk because of their complexity. The construction and operation stages are the core of successful infrastructure PPP projects. This study analysed the efficiency and determinants of the construction and operation stages of Chinese infrastructure PPP projects conducted by thirty provinces from 2008-2013. During the five years examined, the efficiency of infrastructure PPP projects in the construction stage exhibited a downward spiral, but showed a gradual upward trend in the operation stage. The results showed that government supervision was one of the most significant positive influences on construction efficiency, while risk allocation had a greater positive impact on efficiency during the operation stage. The evidence in this study is impactful because it provides insights for practitioners regarding key determinants for improving efficiency in the construction and operation stages of infrastructure PPP projects.
\end{abstract}

Keywords: infrastructure PPP projects, government supervision, risk allocation, construction stage, operation stage.

\section{Introduction}

Public private partnerships (PPPs) have become increasingly popular for the construction of essential public infrastructure, particularly in developing countries such as China. For large-scale infrastructure projects, this association between the public and private sector provides a means for procuring financing and resources, with resulting social and economic benefits for both sides. The partnership comprises a long-term contractual arrangement between public and private sector entities. Various types of contractual arrangements can be made, such as the design-build-operate (DBO), build-operate-transfer (BOT), and build-transfer (BT) methods (Tserng, Russell, Hsu, \& Lin, 2012). However, because of increasing complexity and the sectors involved, existing infrastructure PPP projects have been plagued by risks and have suffered often from poor performance in terms of cost overruns and scheduling delays particularly in developing countries (Xu, Lu, Chan, Skibniewski, \& Yeung, 2012). Hence, PPP projects practice has become a focus of study by scholars in recent years, particularly with regard to risk allocation (Ke, Wang, Chan, \& Lam, 2010; Shrestha, Chan, Aibinu, Chen, \& Martek, 2017), critical successful factors (CSFs) for PPP projects (Galilea \& Medda, 2010; Moszoro, 2014; Osei-Kyei \& Chan, 2015; Liu, Wang, \& Wilkinson, 2016).

Although the normative literature on identification of CSFs for PPPs provides in-depth insights into the project management of infrastructure PPP projects, yet a relevant question still remains unanswered; that is: "what are the critical influencing factors for the efficiency of infrastructure PPP projects by stages?". Essentially, it would be very challenging for practitioners to improve the efficiency of infrastructure PPP projects without a thorough and indepth knowledge on the efficiency and determinants of infrastructure PPP projects by stages. Though there exist extensive bodies of literature on improved approaches for evaluating the efficiency of infrastructure projects. Examples include the Cobb-Douglas (CD) production function (Munnell \& Cook, 1990), cost-benefit models (Girard, Gruber, \& Hurst, 1995) and data envelopment analysis (DEA) (Karkazis \& Thanassoulis, 1998; Afonso \& Fernandes, 2008; Wanke, 2013). However, the above research focused mainly on evaluating the investment efficiency of the projects and selected only economic indicators. In addition, there have been heated debates regarding the assessment of infrastruc-

${ }^{*}$ Corresponding author. E-mail: liuningsky60@hnu.edu.cn 
ture PPP projects using qualitative methods, such as institutional analysis (Zhang, Gao, Feng, \& Sun, 2015). In this regard, very limited empirical research has been undertaken to explore and identify the efficiency and its determinants of infrastructure PPP projects (Chan, Yeung, Calvin, Wang, \& Ke, 2011). However, considering the uniqueness of PPP projects, it is likely their efficiency determinants will differ from the traditionally procured projects (Akintoye, Hardcastle, Beck, Chinyio, \& Asenova, 2003). Therefore, a thorough discussion and empirical research on efficiency and determinants analysis of infrastructure PPP projects in the construction and operation stages is required to complement and further expand both practitioners and researchers understanding of project management of infrastructure PPP projects.

Against this backdrop, this paper aimed to explore the efficiency of Chinese infrastructure PPP projects and identify the key determinants for maintaining good performance that are an integral and critical part of all global infrastructure PPP projects. To achieve this goal, first we evaluated the efficiency of a group of Chinese infrastructure PPP projects conducted by thirty provincial governments from 2008-2013. All the projects were in either the construction stage or the operation stage based on the two-stage DEA model. Then we applied a Tobit regression model to examine the impact of government supervision and risk management on the efficiency of these projects in both the construction and operation stages.

This study contributes to the existing literature in several ways. First, this study is the first to provide new empirical evidence for analysing the efficiency and determinants of infrastructure PPP projects in the construction and operation stages. Second, given the "black box" of the operation process for infrastructure PPP projects, this study aimed to fill this gap by using a two-stage DEA model to evaluate efficiency in both the construction and operation stages. Finally, this study considered the complex characteristics of infrastructure PPP projects in China and established a framework for assessing the efficiency and determinants of projects. This approach complements and extends the work of Tang, Zhen, and Yi-Dong (2008), Li et al. (2009), and Wanke (2013), as well as other studies evaluating the efficiency of infrastructure PPP projects.

This study is important because PPPs have been widely used to deliver infrastructure projects and provide public services in China since the reforms and the opening up in the 1970s. The development of PPPs in China has gone through three stages: exploratory (mid-1980s to 1999), promotion (early 2000s to 2012), and generalization (2013 to the present). The Shenzhen Shajiao B Power Plant, constructed in the mid-1980s, is considered the start of China's adoption of PPPs. According to the latest statistics from the China Public Private Partnerships Center (CPPPC), there were 13,554 PPP projects in the national PPP comprehensive project database, with a total investment of 16.3 trillion RMB by August 16, 2017. China is now considered to be one of the world's most active markets for private sec- tor participation in infrastructure development. Hence, we examined evidence that could be deemed to have special value for improving the performance of infrastructure PPP projects in China and other countries.

This study's findings also have practical implications for the public sector and for private investors, including property scientists interested in PPPs. Specifically, the findings can inform practitioners about strategic management that should be adopted for public participation to meet stakeholders' expectations when implementing infrastructure PPPs in the construction stage. Moreover, government guarantee is an effective and common way to control risks in the operation stage of PPP projects. The findings suggest there is a significant social impact when the responsibilities for property management are clearly divided between practitioners in infrastructure PPP projects. In addition, since the stages of PPP projects have different characteristics, researchers and property scientists should differentiate between them when analysing the efficiency and determinants of infrastructure PPP projects.

The remainder of this paper is organized as follows. Section 1 provides a literature review. Section 2 describes our research methodology and model specifications. In Section 3, we provide an analysis of our empirical results regarding efficiency and the determinants of infrastructure PPP projects in the construction and operation stages. Last section provides our conclusions and recommendations based on the results of this research.

\section{Literature review}

\subsection{Efficiency evaluation of infrastructure PPP projects}

Influenced by Keynesian theories, the main source of infrastructure investment in the mid-20th century was the government. Scholars focused on investigating the impact of government infrastructure investment on economic growth through the Cobb-Douglas (CD) production function, cost-benefit models, and vector regression models. Usually, input was measured in terms of infrastructure investment by the public, labour, and technology sectors, while output was viewed in terms of GDP (Munnell \& Cook, 1990; Girard et al., 1995; Groote, Jacobs, \& Sturm, 1999). With the introduction of new public management theories at the end of the 20th century, challenges were raised concerning the efficiency of government investment. Scholars began to explore private capital participation through multi-input and output methods such as DEA. For example, Karkazis and Thanassoulis (1998) chose central government subsidies in Northern Greece as input variables, and selected the investment proportion of the private sector in the first, second, and tertiary industries as output variables.

At the beginning of the 21st century, a few scholars began to focus on industrial analysis of PPP projects. To estimate PPP project efficiency at the industrial level, they chose as inputs capital investment and the number 
of employees in certain industries. In addition, they used the amount of equipment, physical size of equipment, and number of users in the industry as outputs (Koski \& Majumdar, 2000; Ariff, Cabanda, \& Sathye, 2009). Some investigators focused on comparing the efficiency of interregional projects. Afonso and Fernandes (2008) used the BCC-DEA model to measure the investment efficiency of infrastructure projects from five regions in Portugal in 2001. Per capita municipal expenditures were chosen as the input, while investment in sanitation, road infrastructures, and other infrastructure construction were used as the output (Afonso \& Fernandes, 2008). To measure the investment efficiency of infrastructure PPP projects, Tang et al. (2008) chose government and private investment by infrastructure sectors such as electrical power, transportation, and water as input, and adopted the GDP growth rate as output. Li et al. (2009) evaluated and sorted the investment efficiency of infrastructure projects conducted by provinces or cities in China. Taking external environmental factors into account, other researchers also added social benefits and foreign direct investment (FDI) as input indicators (Hu et al., 2014).

Despite the increased use of DEA to measure the efficiency of infrastructure projects in recent years (e.g., Vitner, Rozenes, \& Spraggett, 2006; Afonso \& Fernandes, 2008; Hung, Lu, \& Wang, 2010; Xu \& Yeh, 2014), few studies recognized explicitly that some intermediate outputs are produced and consumed between infrastructure projects' processes. While the studies based on DEA cited above provided meaningful insights regarding the performance of infrastructure PPP projects, some recent developments in DEA have enabled the study of infrastructure project efficiency through examination of the internal association of factors related to final efficiency (Yao, 2009; Zhu, 2011; Wanke, 2013). For example, Wanke (2013) applied a two-stage DEA model to calculate the efficiency of Brazilian projects divided into a physical infrastructure stage and shipment consolidation stage.

\subsection{Factors influencing the efficiency of infrastructure PPP projects}

During the first decade of the 21st century, scholars relied primarily on mathematical economic models and case study methods to analyze the impact of contract design on the efficiency of infrastructure PPP projects. Their research showed that contract design is one of the most critical factors affecting the efficiency of infrastructure PPP projects. For example, some research indicated that there is incomplete and unreasonable allocation of risk in existing contracts (Debande, 2002). Along with the established theoretical framework of the efficiency of infrastructure PPP projects, other scholars adopted empirical research methods, such as case analysis and questionnaires. Their research focused on the influence of government behaviour on the process of managing infrastructure PPP projects, such as the degree of government corruption (Hammami, Ruhashyankiko, \& Yehoue, 2006), rotation of officials (Martimort \&
Straub, 2009), project bidding (Guasch, Laffont, \& Straub, 2008), and regulatory mechanisms for pricing (Chowdhury \& Charoenngam, 2009), among others.

Since 2010, the diversification of participants in infrastructure PPP projects has grown with time. With the guidance of stakeholder theory, research concentrated on the factors that affect the efficiency of infrastructure PPP projects, such as risk allocation and the responsibility of thirdparty supervision. Galilea and Medda (2010) found that one of the main reasons for failure of infrastructure PPP projects is diversification of investors. While the presence of diverse creditors can be helpful in terms of increased supervision and improved efficiency, their participation also increases both communications costs and the number of incidences of disputes. Chowdhury and Charoenngam (2009) emphasized the value of involving rating agencies, multilateral development banks, and other international institutions to buffer the political risk that may be associated with developing countries. Their involvement ensures some protection for investors, attracts foreign investment, and lowers financing costs for infrastructure PPP projects. Moszoro (2014) argued that government ownership of SPV companies can result in complex management structures and lower efficiency of infrastructure PPP projects. However, it is optimal for governments to participate in these equity investments to ensure lower financing costs, as well as a more stable economic and legal environment for the SPV companies (Moszoro, 2014).

In contrast, research findings regarding the factors influencing the efficiency of infrastructure PPP projects are scattered. Only a few scholars emphasized the effects of government compensation and government credit on the efficiency of infrastructure PPP projects in China (Zhang, 2014). As a consequence of Chinese public ownership, decision-making for infrastructure PPP projects is still government-lead, with the private sector gradually filtering into infrastructure PPP projects.

\section{Research methodology}

\subsection{Data envelopment analysis}

Data envelopment analysis (DEA), a well-known method for measuring the efficiency of decision-making units (DMUs), was introduced more than 40 years ago when Charnes, Cooper, and Rhodes (1978) presented their CCR model. With this model, they could transform the fractional linear measure of efficiency into a linear programming model. DEA, as a research field, has grown rapidly because of its unique ability to measure the efficiency of multiple-input, multiple-output DMUs without assigning prior weights to the input and output. DEA can be used as a decision-analysis tool in several areas because it does not focus on finding universal relationships among all units under assessment in the sample. Rather, DEA allows every unit in the dataset to have its own production function, and then it evaluates the efficiency of that single unit by comparing it with the efficiency of other units in the dataset. 
More specifically, DEA classifies all units into two groups: efficient with a $100 \%$ efficiency score and inefficient with a less than $100 \%$ efficiency score. DEA is used to establish a best-practice group among a set of observed units and to identify units that are inefficient compared to the best-practice group. DEA also indicates the magnitude of inefficiencies and possible improvements for inefficient units. After Charnes et al. (1978) first proposed the CCRDEA model in 1978, which takes constant returns to scale as its premise, DEA models suitable for various situations gradually emerged, such as the BCC model (with variable returns to scale) and three-stage DEA model (Fried, Lovell, Schmidt, \& Yaisawarng, 2002).

The DEA model mentioned above is designed to measure the efficiency of the initial investment of each DMU, and the final output is based on the evaluation of the project. The DMU itself is regarded as a single "black box" structure, so the model ignores the internal process of the DMU occurring between the interaction and transformation processes. The black box hypothesis was previously considered one of the advantages of the DEA method. However, in the actual practice of efficiency evaluation, more and more scholars found that intermediate production processes, consisting mostly of economic activities, have an important influence on the whole production process (Zhu, 2000). In other words, overall low efficiency may be the result of one or more processes that were not evaluated because they were in the black box. Therefore, it is necessary to open the black box to carry out a more detailed analysis of the effectiveness of each phase.

\subsection{Model specification}

\subsubsection{Two-stage DEA model}

Broadly speaking, the life cycle of an infrastructure PPP project can be divided into three stages: construction, operation, and transfer (Ke, Wang, Chan, \& Cheung, 2009). Each stage is interrelated and affects the others, and the overall efficiency of an infrastructure PPP project is the result of the integration of each stage. The largest amounts of input and output are concentrated in the construction stage and operation stage. Taking into account the availability of data and the complexities of infrastructure PPP projects in China, this paper uses the two-stage DEA model to calculate the efficiency of infrastructure PPP projects in both the construction and operation stages.

In the two-stage DEA model, decision-making units (DMUs) can be divided into a two-stage structure in which the output of the first sub-stage is used as input for the second sub-stage (Chen et al., 2009). In summary, input funding (investment) for infrastructure PPP projects is used in Stage 1 to construct the infrastructure. Then the infrastructure moves into Stage 2, the operation stage, creating economic and social benefits. This two-stage process is shown in Figure 1.

In the two-stage DEA model, considering the relationship between the overall process and the sub-processes, there are $n$ DMUs. In the first stage, each DMU has $m$ inputs denoted as $X_{m}$, and each DMU has d outputs denoted as $Z_{d}$. The second stage regards the first stage outputs as the inputs, and the final output is denoted as $Y_{s}$. In this study, $X_{j}=\left(x_{1 j}, x_{2 j}, \ldots, x_{m j}\right)^{\mathrm{T}}, Z_{j}=\left(z_{1 j}, z_{2 j}, \ldots, z_{d j}\right)^{\mathrm{T}}$, and $Y_{j}=\left(y_{1 j}, y_{2 j}, \ldots, y_{s j}\right)^{\mathrm{T}}$. The weight of each input and output variable is $u, v$, and $w$, respectively. $E_{0}$ represents the overall efficiency of the DMUs, and $E_{0}^{1}, E_{0}^{2}$ represent the sub-process efficiency. Thus, the efficiency model of the whole process is shown as (1):

$$
\begin{aligned}
& E_{0}=\max u^{T} Y_{0} / v^{T} X_{0} \\
& \text { s.t. }\left\{\begin{array}{l}
\frac{u^{T} Y_{j}}{v^{T} X_{j}} \leq 1, j=1, \ldots, n \\
\frac{w^{T} Z_{j}}{v^{T} X_{j}} \leq 1, j=1, \ldots, n \\
\frac{u^{T} Y_{j}}{w^{T} Z_{j}} \leq 1, j=1, \ldots, n \\
u \geq 0 ; v \geq 0 ; w \geq 0
\end{array}\right. \\
& \text { s.t. }\left\{\begin{array}{l}
u^{T} Y_{j} / v^{T} X_{j} \leq 1, j=1, \ldots, n \\
w^{T} Z_{j} / v^{T} X_{j} \leq 1, j=1, \ldots, n \\
u^{T} Y_{j} / w^{T} Z_{j} \leq 1, j=1, \ldots, n \\
u \geq 0 ; v \geq 0 ; w \geq 0 .
\end{array}\right.
\end{aligned}
$$

Taking the value of $t=\frac{1}{v^{T} X_{0}} t=1 / v^{T} X_{0}$, and setting the values of $\omega=t v, \pi=t w$, and $\mu=t u$, we transform the fractional programming model into a linear programming model shown as (2):

$$
\begin{aligned}
& E_{0}=\max \mu^{T} Y_{0} \\
& \left\{\begin{array}{c}
\omega^{T} X_{0}=1 \\
\mu^{T} Y_{j}-\omega^{T} X_{j} \leq 0, j=1, \ldots, n \\
\pi^{T} Z_{j}-\omega^{T} X_{j} \leq 0, j=1, \ldots, n \\
\mu^{T} Y_{j}-\pi^{T} Z_{j} \leq 0, j=1, \ldots, n \\
u \geq 0 ; v \geq 0 ; w \geq 0 .
\end{array}\right.
\end{aligned}
$$

The optimal solutions $\omega^{*}, \pi^{*}, \mu^{*}$ can be obtained by the above model, and then the efficiency value of the DMUs can be $E_{0}=\mu^{* \mathrm{~T}} Y_{0}, E_{0}^{1}=\pi^{\star \mathrm{T}} Z_{0}$, and $E_{0}^{2}=\mu^{\star \mathrm{T}} Y_{0} / \pi^{\star \mathrm{T}} Z_{0}$. Thus $E_{0}=E_{0}^{1} \times E_{0}^{2}$.

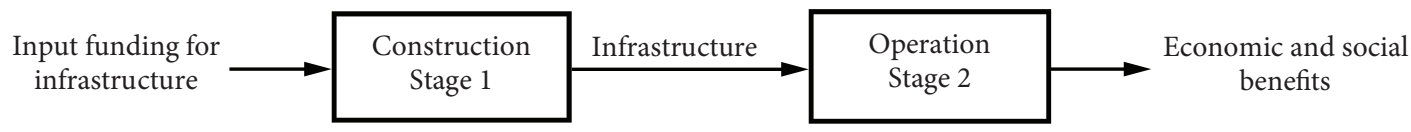

Figure 1. Flow chart of an infrastructure project 


\subsubsection{Two-stage DEA model}

In the process of evaluating the efficiency of infrastructure PPP projects, the two-stage DEA model uses controllable input and output indicators, without considering other uncontrollable external environmental factors. Because the efficiency scores of infrastructure PPP projects are all $[0,1]$, they are part continuous and part discrete distribution data. Consequently, ordinary least squares (OLS) are no longer suitable for estimating the regression coefficient, and the estimation results may appear biased and inconsistent. It is necessary to introduce the Tobit regression method to estimate the regression coefficient.

The Tobit regression model, first proposed by Tobin (1956), is an approach in which the dependent variables are limited. The Tobit model is shown as (3):

$$
Y_{i}=\beta_{0}+\sum \beta^{T} X_{i}+\mu_{i},
$$

where: $Y_{i}$ is the efficiency value of the previous calculations; $X_{i}$ is the explanatory variable; $\beta^{T}$ is the unknown parameter vector, and $\mu_{i}$ is the residual term that follows the standard normal distribution. Because the fixed effect model of Tobit regression is biased under the maximum likelihood estimation, this research uses the Tobit regression model with random effects.

\subsection{Sample, data, and variables}

\subsubsection{Selection of input and output indicators}

(1) Input indicators

PPPs can be defined broadly or narrowly. The broad definition of PPPs covers the various types of cooperation between the government and the private sector, while the narrow definition of PPPs focuses closely on comprehensive, long-term partnerships. In 2015, the Office of the State Council issued the Notice on Guiding Opinions on Promoting Cooperation Mode between Government and Social Capital in the Field of Public Service (No. 42). It noted that PPP projects are public services provided by social capital, and the government pays into social capital according to the performance of PPP projects to ensure that social capital can obtain reasonable returns. The key demarcation between PPP projects and traditional projects concerns whether social capital can participate in traditional govern- ment-funded projects (e.g., power plants, tap water projects, and land development) and share decision-making and revenue rights. In traditional projects, the government assumes the triple role of direct investor, borrower, and manager, and it directly intervenes in the construction of traditional projects. Thus, the participation space for the private sector is very narrow. The risks of traditional projects are almost entirely borne by the government. Traditional projects pay more attention to the financing of the construction stage but less attention to the economic and social benefits of the operation stage (Xu et al., 2012). In PPP projects, social capital enters the whole process of the project (construction, operation, and transfer stages), while the public sector performs the more macrolevel roles of public services, supervision, and management. PPP projects establish a risksharing relationship between government and the private sector (Zhang, Chan, Feng, Duan, \& Ke, 2016).

Because of the involvement of the private sector, China's infrastructure projects are arranged primarily through application of the basic BT and BOT construction and concession models. As the research object for this paper, we chose the macroeconomic data for construction of infrastructure PPP projects conducted by thirty provincial governments (as described further in Section 2.3.3). For the two-stage DEA analysis, infrastructure investment served as an input indicator for the construction stage of infrastructure PPP projects, divided into government fiscal investment, government debt investment, and investment from the private sector.

(2) Intermediate output indicators

The intermediate output indicators were based on the construction levels of infrastructure PPP projects. Because different types of infrastructure indicators for different units cannot be added together simply, this research used comprehensive indicators to reflect the overall level of infrastructure construction by principal component analysis (Zhang, 2014). Principal component analysis is more representative than single infrastructure indicators (J. Zhang, Gao, Fu, \& H. Zhang, 2007; Zhang et al., 2015). The comprehensive indicators of specific intermediate outputs are shown in Table 1.

We performed the KMO test and Bartley's test of sphericity as part of the principle component analysis. By applying these methods, we gathered the rate of cumulative

Table 1. Local infrastructure construction intermediate output indicators

\begin{tabular}{|l|l|l|}
\hline \multicolumn{1}{|c|}{ Infrastructure system } & \multicolumn{1}{|c|}{ Specific indicators } & \multicolumn{1}{c|}{ Unit of measurement } \\
\hline \multirow{2}{*}{ Traffic system } & Road length $\left(\mathrm{X}_{1}\right)$ & Kilometre \\
\cline { 2 - 3 } & The number of bridges $\left(\mathrm{X}_{2}\right)$ & A bridge \\
\hline \multirow{2}{*}{ Energy } & Total electricity consumption $\left(\mathrm{X}_{3}\right)$ & Million kilowatt hours \\
\cline { 2 - 3 } & Total gas supply $\left(\mathrm{X}_{4}\right)$ & Million cubic metres \\
\hline Communication & The number of mobile phone users $\left(\mathrm{X}_{5}\right)$ & Million households \\
\hline Water resources & The total water supply $\left(\mathrm{X}_{6}\right)$ & Million cubic metres \\
\cline { 2 - 3 } & The total amount of sewage treatment $\left(\mathrm{X}_{7}\right)$ & Million cubic metres \\
\hline Ecological environment & The number of public toilets $\left(\mathrm{X}_{8}\right)$ & Units \\
\cline { 2 - 3 } & The number of green areas $\left(\mathrm{X}_{9}\right)$ & Hectare \\
\hline
\end{tabular}


variance and the covariance matrix, as well as the factor score and the factor score coefficient matrix. This research presents some key data sorted by years, as shown in Table 2, Table 3, and Table 4.

As shown in Table 2, the statistical values of the KMO test in each year were above 0.7 , and all the values of Sig. in the Bartlett sphericity test were 0 . None of the variables can exist independently, which indicated that the principal component analysis method was suitable.

The analysis results showed that there was only one factor with an eigenvalue greater than 1 each year, and the cumulative contribution rate was about $80 \%$. The factor basically contained all the indicators to reflect the information, so by that reckoning, the first factor could be the principal component factor index. The characteristic values and contribution rates of the main factors for each year are shown in Table 4.

Using Table 4, this paper could get the comprehensive value of the local infrastructure construction for each year. For example, the infrastructure construction level by local governments in 2008 was the total of $0.950 \mathrm{X}_{1}+0.840 \mathrm{X}_{2}+$ $0.932 \mathrm{X}_{3}+0.337 \mathrm{X}_{4}+0.931 \mathrm{X}_{5}+0.918 \mathrm{X}_{6}+0.967 \mathrm{X}_{7}+$ $0.787 \mathrm{X}_{8}+0.979 \mathrm{X}_{9}$. The calculation would be similar for each of the other years.

\section{(3) Output indicators}

The final output indicators included both the economic and social benefits brought by the completion of infrastructure PPP projects. Economic benefits reflected the economic growth brought by improvements from infrastructure PPP projects that advance the province's productive capacity and investment environment. Infrastructure investment provided direct economic support for a long time into the future. Social benefits, also known as indirect economic benefits, focused on the role of sustainable infrastructure for social progress and development (Li et al., 2009; Sun et al., 2015). Different types of infrastructure improvements resulted in different social benefits. It is difficult to determine the role played by infrastructure in these types of output indicators. Instead, following the research of Li et al. (2009), we used the level of regional urbanization as a proxy variable showing the local social environment. We here used the proportion of urban population as the specific measurement.

To sum up, the input and output indicators for the efficiency of Chinese infrastructure PPP projects in both the construction and operation stages are shown in Table 5.

Table 2. Results of principal component analysis-KMO and Bartlett tests

\begin{tabular}{|c|c|c|c|c|c|c|c|}
\hline \multicolumn{2}{|c|}{ Inspection content } & 2008 & 2009 & 2010 & 2011 & 2012 & 2013 \\
\hline \multicolumn{2}{|c|}{$\begin{array}{l}\text { Sampling sufficiency } \\
\text { KMO measurement }\end{array}$} & 0.753 & 0.761 & 0.740 & 0.782 & 0.808 & 0.820 \\
\hline \multirow{3}{*}{$\begin{array}{l}\text { Bartlett sphericity } \\
\text { test }\end{array}$} & Approximate Chi square & 400.830 & 403.973 & 440.117 & 443.582 & 449.518 & 454.789 \\
\hline & df & 36 & 36 & 36 & 36 & 36 & 36 \\
\hline & Sig. & 0.000 & 0.000 & 0.000 & 0.000 & 0.000 & 0.000 \\
\hline
\end{tabular}

Table 3. Principal component analysis-cumulative variance contribution rate

\begin{tabular}{|l|l|c|c|c|c|c|c|}
\hline \multicolumn{2}{|c|}{ Inspection content } & 2008 & 2009 & 2010 & 2011 & 2012 & 2013 \\
\hline \multirow{2}{*}{$\begin{array}{l}\text { Extract sum of squares } \\
\text { load }\end{array}$} & Factor eigenvalue & 6.814 & 6.894 & 6.971 & 7.335 & 7.331 & 7.263 \\
\cline { 2 - 8 } & \% of the variance & 75.707 & 76.598 & 77.454 & 81.495 & 81.450 & 80.704 \\
\cline { 2 - 8 } & \% of the cumulative & 75.707 & 76.598 & 77.454 & 81.495 & 81.450 & 80.704 \\
\hline
\end{tabular}

Table 4. Principal component analysis results - component matrix

\begin{tabular}{|c|c|c|c|c|c|c|}
\hline Inspection content & 2008 & 2009 & 2010 & 2011 & 2012 & 2013 \\
\hline $\mathrm{X}_{1}$ & 0.950 & 0.940 & 0.948 & 0.945 & 0.949 & 0.943 \\
\hline $\mathrm{X}_{2}$ & 0.840 & 0.849 & 0.822 & 0.823 & 0.826 & 0.821 \\
\hline $\mathrm{X}_{3}$ & 0.932 & 0.929 & 0.931 & 0.923 & 0.923 & 0.923 \\
\hline $\mathrm{X}_{4}$ & 0.337 & 0.372 & 0.385 & 0.657 & 0.656 & 0.640 \\
\hline $\mathrm{X}_{5}$ & 0.931 & 0.939 & 0.952 & 0.955 & 0.951 & 0.938 \\
\hline $\mathrm{X}_{6}$ & 0.918 & 0.930 & 0.940 & 0.950 & 0.954 & 0.950 \\
\hline $\mathrm{X}_{7}$ & 0.967 & 0.966 & 0.971 & 0.975 & 0.965 & 0.957 \\
\hline $\mathrm{X}_{8}$ & 0.787 & 0.810 & 0.838 & 0.879 & 0.882 & 0.895 \\
\hline $\mathrm{X}_{9}$ & 0.979 & 0.975 & 0.973 & 0.973 & 0.971 & 0.969 \\
\hline
\end{tabular}


Table 5. Input and output indicators of the two-stage efficiency of infrastructure PPP projects in China

\begin{tabular}{|l|l|l|}
\hline \multicolumn{1}{|c|}{ Indicators } & \multicolumn{1}{|c|}{ Contents } & \multicolumn{1}{c|}{ Measurement } \\
\hline \multirow{2}{*}{ Input } & Financial investment & Infrastructure investments from central and local financing \\
\cline { 2 - 3 } & Government debt investment & Infrastructure investments from government loans and bonds \\
\cline { 2 - 3 } & Private investment & $\begin{array}{l}\text { Infrastructure investments from foreign sources, raised by the } \\
\text { private sector and other sources }\end{array}$ \\
\hline Intermediate output & Construction level of infrastructure & $\begin{array}{l}\text { Integrated construction level indicators introduced through } \\
\text { principal component analysis }\end{array}$ \\
\hline Output & Economic benefits & Regional per capita GDP, FDI, and fiscal income \\
\cline { 2 - 3 } & Social benefits & Proportion of urban population \\
\hline
\end{tabular}

\subsubsection{Variables in the Tobit model}

(1) Government supervision. Regulation of infrastructure PPP projects included bidding, pricing, service supervision, and other considerations. Taking the availability of data into account, this paper focused mainly on the influence of financial audits of local governments and corruption levels (Grajzl \& Murrel, 2007; Li, Ng, \& Skitmore, 2013; Liu \& Lin, 2012). The financial audits were reflected by the number of violations of local financial rules, and the corruption levels were measured by using the number of cases of corruption and bribery involving public officials.

In addition, this paper used public participation to evaluate the level of external oversight. Under ordinary circumstances, this variable would be measured by the volume of petitions or letters (Asiedu \& Deffor, 2017). However, the China State Letters offices stopped publishing data about the number of letters in March 2013. As an alternative, we used local environmental petitions to measure the approximate level of public participation in infrastructure PPP projects conducted by each province.

The efficiency of infrastructure PPP projects in the construction stage depended largely on whether the bidding system was transparent or whether there was any opportunity for collusion between authorities. If there were any regulatory loopholes, tendering agencies and bidders could be tempted to avoid the bidding process or conduct false bidding, which was an obvious problem (Osei-Kyei \& Chan, 2018a). Therefore, government supervision would have a more significant impact on the construction stage.

(2) Risk allocation. Local governments could spread the financial risks of direct subsidies and the operating risks by signing long-term contracts with private sector companies. This paper used government subsidies received by utility companies to approximate the financial support level of local governments. As for risk taking, this paper used a privatisation index as measurement (Zhang, 2014). The Privatisation Index measurement divides infrastructure PPP projects recorded in the World Bank PPI database into 10 categories, scored from 1 to 10 points, according to their implementation mode, from outsourced to fully private. The lower the degree of private capital participation, or the higher the government risk-taking, the lower the Privatisation Index value. In this way, the aver- age operation risk-taking level of each province is calculated. In this study, therefore, the Privatisation Index is stated against the operation risk for local governments. As in many other economies, the introduction of private capital into once state-controlled sectors has involved significant political and economic risks (Grimsey \& Lewis, 2004). Since the operation stage of infrastructure PPP projects generally has a long duration, that stage faces a variety of political risks, including policy changes, political opposition, and officials' term limits, among other issues ( $\mathrm{Su}$, Mitchell, \& Sirgy, 2007). PPPs allow local governments to transfer more operation risks to the private sector (Hammami et al., 2006). In other words, the Privatisation Index value indicates the operating risk of local governments. In infrastructure PPP projects, a higher Privatisation Index value means the private sector bears a greater operation risk and local governments have less resource commitment (Zhang, 2014). Thus, private investors must configure a contract that clearly shares risk with the government. Accordingly, risk allocation has the most significant effect on the operation stage.

(3) Control variables. When selecting control variables, we identified four significant considerations. First, the institutional environment of infrastructure PPP projects is different in each province. Accordingly, it was necessary for local governments to promulgate a sufficient number of policies to monitor and evaluate the institutional environment. Second, a high degree of financial autonomy meant stronger financial power, ensuring the implementation of infrastructure PPP projects with more adequate financial support. Third, areas with greater economic openness may be more receptive to absorbing foreign investment in domestic infrastructure projects. Finally, as the local financial market developed, the ability to provide adequate thirdparty financing could improve as well. Therefore, for this paper we selected four control variables, including the number of policies relating to infrastructure PPP projects, the degree of financial autonomy of the local government, openness, and financial development. We standardized all the explanatory variables to ensure they fell into the $(0,1)$ interval. According to the above analyses, all factors influencing the efficiency of infrastructure PPP projects in both the construction and operation stages are shown in Table 6. 
Table 6. Factors influencing the efficiency of infrastructure PPP projects

\begin{tabular}{|l|l|l|}
\hline \multicolumn{1}{|c|}{ Index } & \multicolumn{1}{|c|}{ Contents } & \multicolumn{1}{c|}{ Measurement } \\
\hline \multirow{3}{*}{ Supervision } & Financial audit & Number of violations of local financial regulations \\
\cline { 2 - 3 } & Public participation & Number of local environmental petitions \\
\cline { 2 - 3 } & corruption & Number of cases of corruption and bribery of public officials \\
\hline \multirow{3}{*}{ Risk allocation } & Financial risk & Government subsidies received by utilities companies/GDP \\
\cline { 2 - 3 } & Operation risk & Privatisation index \\
\cline { 2 - 3 } & Number of policies & Number of policies relating to PPPs promulgated by local government \\
\cline { 2 - 3 } & Financial autonomy & $\begin{array}{l}\text { Provincial per capita expenditure / (central + provincial per capita expenditure } \\
\text { per capita expenditure) }\end{array}$ \\
\cline { 2 - 3 } & Openness & Total import and export amount/GDP \\
\cline { 2 - 3 } & Financial development & Long-term loans of each province/GDP \\
\hline
\end{tabular}

\subsubsection{Sample and data}

For this research, we selected infrastructure PPP projects developed in thirty provinces in China as the objects of study. Projects in Tibet, Hong Kong, Macao, and Taiwan were excluded because data from those areas were incomplete. Our data were derived from nine sources. Input and intermediate output data were gathered from the China Urban Construction Statistical Yearbook, and output data were from the China Statistical Yearbook. Data concerning the number of local financial violations were taken from the China Audit Yearbook, the number of local environmental petitions was acquired from the China Environment Statistical Yearbook, and the number of incidents of corruption and bribery of public officials was gathered from the China Attorney Yearbook. Financial risk data were provided by the CSMAR database, and operating risk data were from the World Bank PPI database. Data regarding the number of related policies were generated by searching the Peking University Law Legal Database using "PPP", "BOT", "BT", and "concession" as keywords. Financial autonomy data were from Finance Statistics Yearbook, data regarding openness were from the China Statistical Yearbook, and financial development data were from the Financial Statistics Yearbook. Our sample covered the period from 2008-2013. This research was extended only through 2013 because financial audit supervision indicators were updated only to 2013. This paper used MATLAB 7.0 simulation software to deal with missing data according to the rules of data change.

\section{Research results}

\subsection{Efficiency of Chinese infrastructure PPP projects in the construction and operation stages}

MATLAB 7.0 programming software was used to calculate the two-stage DEA model of the efficiency of infrastructure PPP projects in both the construction and operation stages. The results are shown in Table 7. As shown in Table 7, the construction efficiency of infrastructure PPP projects fluctuated greatly as a whole. Infrastructure PPP projects in Shanghai kept a leading position on the effi- ciency front. In comparison, infrastructure PPP projects in some western regions such as Qinghai and Ningxia maintained the highest levels of construction efficiency as well, even though they were faced with poor economic foundations. However, the construction efficiency of infrastructure PPP projects in Beijing, Hebei, and Fujian provinces presented the strongest rising trend. In 2007, Fujian province standardized the municipal engineering bidding process for infrastructure PPP projects, and gradually introduced a series of beneficial management measures including budget preparation, final acceptance management, and quality supervision, among other steps. Thus, the construction efficiency of infrastructure PPP projects in Fujian province showed an increase year after year. At the same time, the construction efficiency of infrastructure PPP projects in Gansu, Xinjiang, Guizhou, and Heilongjiang provinces showed a decrease year after year. These results were a consequence of huge infrastructure investment needs, poor natural conditions with high capital costs, and lack of institutional structures such as a bidding system for infrastructure projects, contract management, and quality supervision.

Overall, for the years examined, improvement in efficiency during the operation stage of infrastructure PPP projects progressed smoothly in comparison to fluctuations in efficiency during the construction stage. The efficiency of the operation stage of infrastructure PPP projects fell in 2009 only. In addition, the infrastructure PPP projects in Tianjin, Inner Mongolia, and Hainan provinces consistently remained front-runners in terms of efficiency in the operation stage. However, the outlook for the efficiency of infrastructure PPP project operations in most of the developed areas, such as Beijing, Shanghai, and Shandong provinces, was not optimistic. These findings might have resulted from redundant investment and excessive construction that finally lost the scale effect of new infrastructure PPP projects. Thus, there was no obvious increase in the growth of social and economic development in those regions. The efficiency of infrastructure PPP project operations in Guangdong province showed the most pronounced fluctuations in 2008, and kept a downward trend until experiencing a sharp rise in 2013. 
Table 7. Efficiency of Chinese infrastructure PPP projects in the construction and operation stages

\begin{tabular}{|c|c|c|c|c|c|c|c|c|c|c|c|c|}
\hline & \multicolumn{6}{|c|}{ Construction } & \multicolumn{6}{|c|}{ Operation } \\
\hline & 2008 & 2009 & 2010 & 2011 & 2012 & 2013 & 2008 & 2009 & 2010 & 2011 & 2012 & 2013 \\
\hline Beijing & 0.53 & 0.42 & 0.54 & 0.74 & 0.84 & 0.78 & 0.38 & 0.33 & 0.30 & 0.26 & 0.24 & 0.24 \\
\hline Tianjin & 0.53 & 0.41 & 0.24 & 0.44 & 0.22 & 0.47 & 1.00 & 1.00 & 1.00 & 1.00 & 1.00 & 1.00 \\
\hline Hebei & 0.20 & 0.21 & 0.19 & 0.21 & 0.36 & 0.51 & 0.55 & 0.49 & 0.52 & 0.49 & 0.52 & 0.51 \\
\hline Shanxi & 0.62 & 0.34 & 0.38 & 0.60 & 0.48 & 1.00 & 0.76 & 0.68 & 0.70 & 0.59 & 0.77 & 0.58 \\
\hline Inner Mongolia & 0.48 & 0.25 & 0.16 & 0.32 & 0.36 & 0.49 & 1.00 & 1.00 & 1.00 & 0.96 & 0.99 & 1.00 \\
\hline Liaoning & 0.28 & 0.28 & 0.33 & 0.19 & 0.18 & 0.30 & 0.66 & 0.70 & 0.77 & 0.86 & 0.98 & 0.93 \\
\hline Jilin & 0.62 & 0.39 & 0.64 & 0.37 & 0.51 & 0.61 & 0.50 & 0.49 & 0.49 & 0.58 & 0.56 & 0.57 \\
\hline Heilong jiang & 0.63 & 0.33 & 0.45 & 0.27 & 0.19 & 0.26 & 0.40 & 0.39 & 0.41 & 0.45 & 0.48 & 0.47 \\
\hline Shanghai & 0.86 & 1.00 & 1.00 & 1.00 & 1.00 & 1.00 & 0.70 & 0.64 & 0.64 & 0.59 & 0.57 & 0.56 \\
\hline Jiangsu & 0.35 & 0.32 & 0.27 & 0.23 & 0.23 & 0.22 & 0.74 & 0.69 & 0.65 & 0.64 & 0.63 & 0.62 \\
\hline Zhejiang & 0.29 & 0.22 & 0.44 & 0.30 & 0.23 & 0.16 & 0.75 & 0.70 & 0.74 & 0.74 & 0.70 & 0.64 \\
\hline Anhui & 0.37 & 0.44 & 0.31 & 0.18 & 0.16 & 0.14 & 0.41 & 0.45 & 0.51 & 0.54 & 0.60 & 0.61 \\
\hline Fujian & 0.19 & 0.24 & 0.38 & 0.32 & 0.24 & 0.51 & 0.79 & 0.71 & 0.70 & 0.73 & 0.65 & 0.70 \\
\hline Jiangxi & 0.41 & 0.39 & 0.18 & 0.09 & 0.09 & 0.11 & 0.68 & 0.64 & 0.70 & 0.78 & 0.90 & 0.88 \\
\hline Shandong & 0.53 & 0.22 & 0.46 & 0.45 & 0.92 & 0.49 & 0.54 & 0.51 & 0.54 & 0.51 & 0.50 & 0.48 \\
\hline Henan & 0.58 & 0.40 & 1.00 & 0.38 & 0.42 & 0.36 & 0.51 & 0.48 & 0.51 & 0.54 & 0.58 & 0.58 \\
\hline Hubei & 1.00 & 0.28 & 0.61 & 0.64 & 0.43 & 0.53 & 0.29 & 0.30 & 0.32 & 0.37 & 0.39 & 0.40 \\
\hline Hunan & 0.37 & 0.27 & 0.31 & 0.25 & 0.28 & 0.23 & 0.45 & 0.45 & 0.46 & 0.52 & 0.54 & 0.54 \\
\hline Guang dong & 0.94 & 0.61 & 0.36 & 0.85 & 0.84 & 0.70 & 0.52 & 0.50 & 0.50 & 0.37 & 0.38 & 1.00 \\
\hline Guangxi & 0.37 & 0.42 & 0.29 & 0.26 & 0.20 & 0.16 & 0.41 & 0.42 & 0.44 & 0.48 & 0.44 & 0.45 \\
\hline Hainan & 0.56 & 0.64 & 1.00 & 1.00 & 0.58 & 0.68 & 1.00 & 1.00 & 1.00 & 1.00 & 1.00 & 1.00 \\
\hline Chong qing & 0.21 & 0.25 & 0.26 & 0.24 & 0.22 & 0.21 & 0.54 & 0.54 & 0.61 & 0.69 & 0.68 & 0.60 \\
\hline \begin{tabular}{|l} 
Sichuan \\
\end{tabular} & 0.49 & 0.46 & 0.55 & 0.52 & 0.39 & 0.43 & 0.40 & 0.39 & 0.47 & 0.44 & 0.46 & 0.46 \\
\hline Guizhou & 0.89 & 0.74 & 0.77 & 0.37 & 0.22 & 0.08 & 0.90 & 0.94 & 0.97 & 1.00 & 1.00 & 1.00 \\
\hline Yunnan & 0.52 & 0.32 & 0.18 & 0.31 & 0.41 & 0.22 & 0.98 & 0.91 & 0.91 & 0.93 & 1.00 & 1.00 \\
\hline Shannxi & 0.25 & 0.21 & 0.21 & 0.21 & 0.17 & 0.15 & 0.62 & 0.59 & 0.67 & 0.73 & 0.61 & 0.59 \\
\hline Gansu & 1.00 & 0.57 & 0.67 & 0.60 & 0.46 & 0.24 & 0.48 & 0.46 & 0.48 & 0.46 & 0.43 & 0.43 \\
\hline Qinghai & 0.90 & 1.00 & 0.72 & 0.91 & 0.82 & 1.00 & 0.88 & 0.70 & 1.00 & 0.98 & 0.75 & 0.80 \\
\hline Ningxia & 1.00 & 1.00 & 1.00 & 1.00 & 1.00 & 1.00 & 0.67 & 0.78 & 0.56 & 0.59 & 0.48 & 0.49 \\
\hline Xingjiang & 0.76 & 0.47 & 0.69 & 0.41 & 0.29 & 0.28 & 0.49 & 0.43 & 0.45 & 0.43 & 0.37 & 0.34 \\
\hline Average & 0.56 & 0.44 & 0.49 & 0.46 & 0.43 & 0.44 & 0.63 & 0.61 & 0.64 & 0.65 & 0.65 & 0.66 \\
\hline
\end{tabular}

Also, the efficiency of the operation stage of infrastructure PPP projects in Ningxia province presented the greatest significant decrease.

At this point, this paper offers further analysis of the efficiency of Chinese infrastructure PPP projects in both the construction and operation stages. Our results showed that the average efficiency of infrastructure PPP projects was valued at 0.47 in the construction stage and 0.63 in the operation stage. The areas that had double-high efficiency scores (i.e., strong performance in both the construction and operation stages) for infrastructure PPP projects included Hainan, Qinghai, Shanxi, and Guizhou provinces. Most of infrastructure PPP projects were in underdeveloped areas, but they rendered good performance in both the construction and operation stages. The fundamental factors that promoted double-high efficiency were central government support and preferred tax status, as well as low land and labour costs. Therefore, the ratio of infrastructure investment to GDP output had greater elasticity.

In contrast, the infrastructure PPP projects that had double-low efficiency scores (i.e., weak performance in both the construction and operation stages) were located in Chongqing, Anhui, Shandong, Hunan, Guangxi, and Heilongjiang provinces. Essentially, the economic foundation determines the construction level of infrastructure PPP projects (Ke et al., 2010). Most of these areas are central Chinese provinces faced with poor economic fundamentals and an absence of preferential policies, except for Shandong. Compared to the eastern region, the central and western regions are susceptible to financial constraints because of imbalanced economic and social development, and local government budgets for infrastructure construc- 
tion are insufficient. Furthermore, the provinces that had infrastructure PPP projects with high operating efficiency accompanied by construction inefficiency included Inner Mongolia, Tianjin, Yunnan, Liaoning, Jiangxi, Fujian, Jiangsu, and Shaanxi provinces. The areas that had projects with high construction efficiency and low operating efficiency included Henan, Jilin, Gansu, Sichuan, Xinjiang, Hubei, Beijing, Guangdong, and Shanghai provinces. These results suggested that infrastructure PPP projects in these provinces experienced unbalanced development between the infrastructure construction and operation stages.

\subsection{Determinants analysis of construction and operations efficiency of Chinese infrastructure PPP projects}

This paper used panel data of infrastructure PPP projects from 2008-2013, and a Tobit regression model with random effects. Model 1 and Model 2 analysed factors influencing the efficiency of infrastructure PPP projects in the construction stage, and Model 3 and Model 4 analysed factors influencing efficiency in the operation stage. Model 1 and Model 3 considered the impact of all the explanatory variables on the efficiency of infrastructure PPP projects during the construction and operation stages. Model 2 investigated only the influence of supervision on the efficiency of infrastructure PPP projects in the construction stage. Model 4 examined only how risk allocation affected the efficiency of projects in the operation stage. Table 8 shows the regression results calculated by STATA14.0. Overall, the Rho value of each of the four models was more than 0.6 , indicating that the individual effects explained changes in the efficiency of infrastructure PPP projects in the construction and operation stages. The results of the regression analyses can be understood as follows.

Based on the above empirical results, Model 1 and Model 2 demonstrated that the efficiency of infrastructure PPP projects in the construction stage was affected significantly by the level of government supervision. This coincides with Sengupta (2006) and Xu et al. (2010), who found that the government's responsibility in PPPs is to ensure adequate supervision according to the theory of public goods. Government supervision ensures construction partnership efficiency and optimises available resources in line with broader policy objectives. Meanwhile, the government and the private sector exist in a principalagent relation in PPP projects. Due to asymmetric information, the private sector often neglects the social benefits of projects to make profits, and moral hazards arise, such as rent-seeking rights. Van Rijckeghem and Weder (2001) noted that the degree of economic fundamentals negatively correlates with regional corruption. In the central and western regions, where economic foundations are relatively poor, government supervision is not transparent, which can breed corruption and cause inefficiency (Sengupta, 2006; Xu et al., 2010). Similarly, Hammami et al. (2006) used the World Bank's PPI database to verify the correlation between the government's ability to control corruption and the investment performance of PPP pro-

Table 8. Tobit regression results analysis

\begin{tabular}{|c|c|c|c|c|}
\hline & $\begin{array}{c}\text { Model } 1 \\
\text { Te1 }\end{array}$ & $\begin{array}{c}\text { Model } 2 \\
\text { Te1 }\end{array}$ & $\begin{array}{c}\text { Model } 3 \\
\text { Te2 }\end{array}$ & $\begin{array}{c}\text { Model } 4 \\
\text { Te} 2\end{array}$ \\
\hline Financial audit & $\begin{array}{c}-0.1548^{* *} \\
(-1.96)\end{array}$ & $\begin{array}{c}-0.3234^{*} \\
(-1.77)\end{array}$ & $\begin{array}{c}-0.2547 \\
(-0.64)\end{array}$ & \\
\hline Public participation & $\begin{array}{c}-0.0335 \\
(-0.38)\end{array}$ & $\begin{array}{c}-0.0309 \\
(-0.36)\end{array}$ & $\begin{array}{l}-0.1016 \\
(-0.22)\end{array}$ & \\
\hline Corruption & $\begin{array}{c}-0.3118^{*} \\
(-1.79)\end{array}$ & $\begin{array}{c}-0.1397^{\star} \\
(-1.86)\end{array}$ & $\begin{array}{c}-0.0508 \\
(-0.05)\end{array}$ & \\
\hline Financial risk & $\begin{array}{c}-0.0810 \\
(-1.60)\end{array}$ & & $\begin{array}{c}-0.0052 \\
(-0.21)\end{array}$ & $\begin{array}{c}-0.0333 \\
(-0.14)\end{array}$ \\
\hline Operation risk & $\begin{array}{c}-0.1544 \\
(-0.57)\end{array}$ & & $\begin{array}{c}-0.3466^{\star *} \\
(-2.05)\end{array}$ & $\begin{array}{c}-0.3272^{\star x} \\
(-1.97)\end{array}$ \\
\hline Number of policies & $\begin{array}{l}-0.0586 \\
(-0.31)\end{array}$ & $\begin{array}{c}-0.0797 \\
(-0.43)\end{array}$ & $\begin{array}{c}-0.1942^{\star} \\
(-1.87)\end{array}$ & $\begin{array}{c}-0.1965^{\star} \\
(-1.99)\end{array}$ \\
\hline Financial autonomy & $\begin{array}{c}-1.2953^{* *} \\
(-2.48)\end{array}$ & $\begin{array}{c}-1.2100^{\star *} \\
(-2.38)\end{array}$ & $\begin{array}{c}0.7335^{\star *} \\
(2.73)\end{array}$ & $\begin{array}{c}0.7713^{* * \star} \\
(3.13)\end{array}$ \\
\hline Openness & $\begin{array}{c}0.4401^{\star} \\
(1.87)\end{array}$ & $\begin{array}{c}0.3775^{\star} \\
(1.84)\end{array}$ & $\begin{array}{l}0.2056 \\
(1.32)\end{array}$ & $\begin{array}{c}0.2023 \\
(1.39)\end{array}$ \\
\hline Financial development & $\begin{array}{c}-0.0406 \\
(-0.29)\end{array}$ & $\begin{array}{c}-0.0351 \\
(-0.25)\end{array}$ & $\begin{array}{c}-0.1942 \\
(-1.36)\end{array}$ & $\begin{array}{c}-0.1221 \\
(-1.56)\end{array}$ \\
\hline Constant & $\begin{array}{c}1.7233^{* * *} \\
(4.20)\end{array}$ & $\begin{array}{c}1.6314^{* * *} \\
(4.06)\end{array}$ & $\begin{array}{c}0.1632 \\
(0.78)\end{array}$ & $\begin{array}{l}0.1220 \\
(0.68)\end{array}$ \\
\hline Log likelihood & 113.1638 & 111.7555 & 117.4431 & 117.1804 \\
\hline Rho & 0.6811 & 0.6744 & 0.8883 & 0.8906 \\
\hline
\end{tabular}


jects. Infrastructure PPP projects developed under a more secure financial system and lower levels of corruption showed significantly better performance in terms of efficiency. By comparison, public participation in supervision had no significant effect on the efficiency of infrastructure PPP projects, reflecting the imperfect nature of China's public participation system. Public engagement in China is still relatively weak, due to not only the cost implications but also the possible delays that could be caused by public engagement. The problems of public engagement in PPP projects in China include the following: a lack of specific legislation or guidelines for public engagement in terms of content and procedures, no enthusiasm among construction practitioners to carry out public engagement since it could cause delays and increase costs, the traditional Chinese culture being conservative in voicing opinions, and insufficient participation by some groups (e.g. women, the elderly, and minorities) in the engagement process (Li, Ng, \& Skitmore, 2012). In the absence of trust between the government and the public, public engagement is often a merely routine bureaucratic process in mainland China, where the implementation of participatory mechanisms is still in its infancy (Li et al., 2013). Compared to mainland China, a framework is still absent in the case of Hong Kong (A. P. C. Chan, Lam, D. W. Chan, Cheung, \& Ke, 2009). The 'Introductory Guide to PPP', established by the Hong Kong government's Efficiency Unit, provides little information about the requirements for public engagement or specific mechanisms that can be adopted in the public engagement process for PPP projects. This may cause confusion for practitioners when trying to engage the public for PPP projects, which could lead to project delays (Ng, Y. M. W. Wong, \& J. M. W. Wong, 2012; Ng, J. M. W., Wong, \& K. K. W. Wong, 2013). As the importance of public engagement increases, more effort needs be invested in improving the mechanism of public engagement.

Regarding the control variables, the impact of an open environment was noticeably positive during the construction stage. Openness increased the participation of foreign capital effectively and attracted advanced management techniques, thus promoting improvements in construction efficiency. The degree of financial autonomy had a significantly negative impact on the efficiency of infrastructure PPP projects during the construction stage. In general, local governments that have more financial autonomy have greater financial strength and feel freer to act. However, financial autonomy might also lead local governments to increase their investment in infrastructure PPP projects without sufficient consideration of market demand and background costs, such as the challenge of potential competition. Blind pursuit of high GDP growth by Chinese officials ultimately could reduce the efficiency of infrastructure PPP projects during the construction stage. In contrast, the level of financial development and the number of related legislative actions were not significant influences, suggesting that the private sectors had difficulty obtaining sufficient funding in lending markets. Therefore, China should continue to strengthen legislative support of the private sector to bolster participation.

Moreover, Model 3 and Model 4 showed that in comparison to supervision, risk allocation had a greater critical influence on the efficiency of infrastructure PPP projects in the operation stage. Of note was the strongly negative impact of lower levels of government involvement. This finding indicated that the operation efficiency of infrastructure PPP projects became lower as more risk was transferred to the private sector. Absence of government guarantees and other comprehensive support, such as risk compensation and tax incentives, were to blame. Government guarantee is an effective and common way to attract private sectors and control risks in the operation stage of PPP projects (Gilberto, 2000; Hammami et al., 2006; Wang, Cui, \& Liu, 2018). Examples include the Laibin B power plant in Guangxi Province and Beijing Subway Line 4 , where the central government and provincial governments offer loan and revenue guarantees to help reduce the risks of private investors. Infrastructure PPP projects are characterised by large investment amounts, long operation stages, and loan contracts with no recourse or limited recourse. To reduce the operational risks of enterprises and banks, it is necessary for the government to provide guarantees for infrastructure PPP projects in the operation stage (Ashiuri, Kashiani, \& Molenaar, 2002). When a PPP project company is unable to continue operating a project because of risks, a government guarantee can encourage the bank to provide additional loans to ensure continued operation. This helps to avoid the loss of social efficiency caused by early project termination and guarantees the stability of infrastructure services (Wibowo, 2004; Wibowo et al., 2012). The private sector elements of PPP projects in mainland China are quite different from those in Western countries. State-owned enterprises, including central and local state-owned enterprises, are the most common private sectors for PPP projects in mainland China. In particular, large state-owned construction enterprises - such as China State Construction Engineering Corporation (CSCEC), China Railway Engineering Corporation (CREC), and China Communication Construction Corporation (CCCC) - are the main forces participating in PPP projects. The participation of state-owned enterprises in PPP projects has natural political advantages, and it is common for a large proportion of financial subsidies to be granted to state-owned enterprises with political connections in mainland China (Zhang et al., 2016; Osei-Kyei \& Chan, 2018b). However, state-owned construction enterprises mainly participate in the construction stage of PPP projects and lack the ability to operate or manage in the operation stage (Osei-Kyei, Chan, Javed, \& Ameyaw, 2017). As a result, the influence of financial support from local governments does not significantly affect infrastructure PPP efficiency in the operation stage. Consequently, risk-sharing models cannot play their intended role (Zhang et al., 2015). 
Among control variables, the most noteworthy result was that financial autonomy generated a significantly positive impact on the efficiency of infrastructure PPP projects in the operation stage, while the impact on the efficiency of infrastructure PPP projects in the construction stage was significantly negative. A higher degree of financial autonomy allowed local governments to provide more sufficient financial support over the long operating period of infrastructure PPP projects, along with more consistent policy commitments.

\section{Implications for infrastructure PPP projects}

This study's findings have several implications for the practise of infrastructure PPP projects, for both the public sector and private investors, including property scientists interested in PPPs. Specifically, the findings can guide practitioners regarding strategic management that should be adopted for public participation to meet stakeholders' expectations in the construction stage. The results indicate that the level of government supervision is the most influential factor in the efficiency of infrastructure PPP projects in the construction stage. Sengupta (2006) noted that the government's responsibility in PPPs is to ensure adequate supervision to ensure construction efficiency. It is very important to clearly divide management responsibilities between the central government and local governments. To prevent the pursuit of short-term benefits, the central government should focus on large-scale infrastructure projects with significant social impact. Since local governments are the initiators and managers of most infrastructure PPP projects, projects should be selected according to feasibility analyses by local governments. Further, it is essential to establish specialised authorities and associated organisations to manage infrastructure PPP projects, whose function should be to supervise pre-project approval, selection, and contract management. These departments would also conduct mid-cycle performance evaluations, supervise post-project evaluations, and issue summaries of the results of completed infrastructure projects. The results also indicate that public engagement is another important influencing factor in constructionstage project efficiency, based on satisfying the need for public service. This suggests that private investors and public sectors should adopt adequate measures to meet the core needs of the public. Further, the private sector should disclose information about project construction that is conducive to public supervision and the improvement of construction efficiency. This will enable the public sector to establish an effective mechanism for engagement in infrastructure PPP projects.

The results also show that risk allocation is critical for project efficiency in the operation stage. This is not surprising since infrastructure PPP projects have long operation stages, and their loan contracts have no recourse or limited recourse. Therefore, it is recommended that the public sector provide guarantees for infrastructure PPP projects in the operation stage to reduce the operational risks of private investors. Further, it is necessary to set up mixed-ownership special-purpose-vehicle (SPV) companies to isolate risks between governments and private sector investors. SPV companies should receive joint investments from the government, the private sector, and appropriate third parties. SPV companies should also allocate financial and operating risks reasonably to the stakeholders who can best manage those risks. For example, the central government should commit to monitoring changes in demand and policy, thereby shifting inflation risk. The private sector should bear the risks of cost overruns, construction timeouts, and controllable risk behaviours on the part of private industries. Third parties could assume the remaining risks.

This study's findings also suggest the need for an improved evaluation process for good value for money in infrastructure PPP projects. Feasibility and the bidding process should be evaluated in the construction stage to determine whether private sector participation is achieving a high degree of good value for money. Moreover, the evaluation index of good value for money for infrastructure PPP projects should be refined according to stage (Hu et al., 2014). Specifically, the evaluation index of good value for money in the construction stage includes construction costs, construction time, and the physical properties of the facility. Construction cost mainly refers to the design, construction, upgrading, renovation, and overhaul expenses of PPP projects, as well as the value of fixed assets, land use rights, and intangible assets. The operationstage evaluation index includes operating costs, operating risks, and quality of services. Operating cost mainly refers to raw materials, equipment, and labour expenses, as well as management expenses, selling expenses, and financial expenses arising from both long- and short-term loans. Thus, local government assessments can complement the evaluation indexes of infrastructure PPP projects or adjust index weights according to various infrastructure PPP project types and industry characteristics.

\section{Conclusions}

China will continue to need increasing numbers of infrastructure PPP projects to support its growing economy. This paper used data from infrastructure PPP projects conducted by thirty provincial governments in China from 2008-2013 to evaluate the efficiency of infrastructure PPP projects in both the construction and operation stages. In addition, we conducted an analysis of the factors that influenced the efficiency of the construction and operation phases of the projects. Our findings indicated that for operational efficiency of the infrastructure PPP projects from 2008-2013, efficiency improvements progressed smoothly in the operation stage as compared to fluctuations in efficiency during the construction stage. Infrastructure PPP projects in Qinghai, Ningxia, and Shanghai provinces were highly efficient in the construction stage. Infrastructure PPP projects in Beijing rose the most in construction efficiency, but demonstrated poor efficiency in the operation 
stage because of the descending scale effect. In addition, the level of government supervision had a greater impact on the construction efficiency of infrastructure PPP projects, while the efficiency of projects in the operation stage was affected significantly by risk allocation.

This study's results reveal the efficiency and determinants of Chinese infrastructure PPP projects in the construction and operation stages. This research contributes to the study of efficiency evaluation strategies and provides practical information for the application and implementation of infrastructure PPP projects. It also identifies the factors that influence the efficiency of infrastructure PPP projects in the construction and operation stages and that maximise the benefits derived from implementing PPP strategies. Furthermore, with the development of infrastructure PPP projects and the database transparency of CPPPC, it is of great value to include preparation and transfer stage data for infrastructure PPP projects in the empirical study. Further research is needed on how to establish a comprehensive infrastructure PPP project efficiency evaluation system in consideration of more political factors.

\section{Acknowledgements}

The authors would like to thank the National Natural Science Foundation of China for its financial support of this research (Grant No. 71774050 and 71573075).

\section{Author contributions}

LiPing Xu and Ning Liu conceived the study and were responsible for the design and development of the data analysis. ShuXia Zhang, HuangJing Qiu and Li Chen were responsible for data collection and analysis. Zeyu Wang and Ning Liu were responsible for data interpretation. Ning Liu wrote the first draft of the article.

\section{Disclosure statement}

The authors declare no conflict of interest.

\section{References}

Afonso, A., \& Fernandes, S. (2008). Assessing and explaining the relative efficiency of local government. The Journal of SocioEconomics, 37(5), 1946-1979.

https://doi.org/10.1016/j.socec.2007.03.007

Akintoye, A., Hardcastle, C., Beck, M., Chinyio, E., \& Asenova, D. (2003). Achieving best value in private finance initiative project procurement. Construction Management and Economics, 21(5), 461-470.

https://doi.org/10.1080/0144619032000087285

Ariff, M., Cabanda, E., \& Sathye, M. (2009). Privatization and performance: evidence from telecommunications sector. Journal of the Operational Research Society, 60(10), 1315-1321. https://doi.org/10.1057/jors.2008.103

Asiedu, K. F., \& Deffor, E. W. (2017). Fighting corruption by means of effective internal audit function: evidence from the
Ghanaian public sector. International Journal of Auditing, 21, 82-99. https://doi.org/10.1111/ijau.12082

Ashiuri, B. H., Kashiani, K. R., \& Molenaar, S. L. (2002). Valuing government guarantees in the toll road project. Journal of Construction Engineering and Management, 12(4), 326-330.

Chan, A. P. C., Lam, P. T., Chan, D. W., Cheung, E., \& Ke, Y. (2009). Drivers for adopting public private partnerships-empirical comparison between China and Hong Kong special administrative region. Journal of Construction Engineering and Management, 135(11), 1115-1124.

https://doi.org/10.1061/(ASCE)CO.1943-7862.0000088

Chan, A. P. C., Yeung, J. F., Calvin, C. P., Wang, S. Q., \& Ke, Y. (2011). Empirical study of risk assessment and allocation of public-private partnership projects in China. Journal of Management in Engineering, 27(3), 136-148.

https://doi.org/10.1061/(ASCE)ME.1943-5479.0000049

Charnes, A., Cooper, W. W., \& Rhodes, E. (1978). Measuring the efficiency of decision making units. European Journal of Operational Research, 2(6), 429-444.

https://doi.org/10.1016/0377-2217(78)90138-8

Chowdhury, A. N., \& Charoenngam, C. (2009). Factors influencing finance on IPP projects in Asia: a legal framework to reach the goal. International Journal of Project Management, 27(1), 51-58. https://doi.org/10.1016/j.ijproman.2008.01.011

Debande, O. (2002). Private financing of transport infrastructure an assessment of the UK experience. Journal of Transport Economics and Policy, 36(3), 355-387. Retrieved from http:// www.jstor.org/stable/20053911

Fried, H. O., Lovell, C. A. K., Schmidt, S. S., \& Yaisawarng, S. (2002). Accounting for environmental effects and statistical noise in data envelopment analysis. Journal of Productivity Analysis, 17(1-2), 157-174.

https://doi.org/10.1023/A:1013548723393

Galilea, P., \& Medda, F. (2010). Does the political and economic context influence the success of a transport project? An analysis of transport public-private partnerships. Research in Transportation Economics, 30(1), 102-109.

https://doi.org/10.1016/j.retrec.2010.10.011

Girard, J., Gruber, H., \& Hurst, C. (1995). Increasing public investment in Europe: some practical considerations. European Economic Review, 39(3-4), 731-738. https://doi.org/10.1016/0014-2921(94)00080-J

Grajzl, P., \& Murrell, P. (2007). Allocating lawmaking powers: self-regulation vs government regulation. Journal of Comparative Economics, 35(3), 520-545. https://doi.org/10.1016/j.jce.2007.01.001

Grimsey, D., \& Lewis, M. K. (2004). Public private partnerships: the worldwide revolution in infrastructure provision and project finance. Northampton, MA: Edward Elgar. https://doi.org/10.4337/9781845423438

Groote, P., Jacobs, J., \& Sturm, J. E. (1999). Infrastructure and economic development in the Netherlands, 1853-1913. European Review of Economic History, 3(2), 233-251. https://doi.org/10.1017/S1361491699000118

Guasch, J. L., Laffont, J.-J., \& Straub, S. (2008). Renegotiation of concession contracts in Latin America: evidence from the water and transport sectors. International Journal of Industrial Organization, 26(2), 421-442. https://doi.org/10.1016/j.ijindorg.2007.05.003

Hammami, M., Ruhashyankiko, J.-F., \& Yehoue, E. B. (2006). Determinants of public-private partnerships in infrastructure. In IMF Working Paper (No. 06/99). Retrieved from https://www. imf.org/external/pubs/ft/wp/2006/wp0699.pdf 
Hung, S. W., Lu, W. M., \& Wang, T. P. (2010). Benchmarking the operating efficiency of Asia container ports. European Journal of Operational Research, 203(3), 706-713. https://doi.org/10.1016/j.ejor.2009.09.005

Karkazis, J., \& Thanassoulis, E. (1998). Assessing the effectiveness of regional development policies in northern Greece using data envelopment analysis. Socio-Economic Planning Sciences, 32(2), 123-137. https://doi.org/10.1016/S0038-0121(97)00023-2

Ke, Y., Wang, S. Q., Chan, A. P. C., \& Cheung, E. (2009). Research trend of public-private partnership in construction journals. Journal of Construction Engineering and Management, 135(10), 1076-1086. https://doi.org/10.1061/(ASCE)0733-9364(2009)135:10(1076)

Ke, Y., Wang, S., Chan, A. P. C., \& Lam, P. T. I. (2010). Preferred risk allocation in China's public-private partnership (PPP) projects. International Journal of Project Management, 28(5), 482-492. https://doi.org/10.1016/j.ijproman.2009.08.007

Koski, H. A., \& Majumdar, S. K. (2004). Convergence in telecommunications infrastructure development in OECD countries. Information Economics \& Policy, 12(2), 111-131. https://doi.org/10.1016/S0167-6245(00)00003-2

Li, T. H. Y., Ng, S. T., \& Skitmore, M. (2013). Evaluating stakeholder satisfaction during public participation in major infrastructure and construction projects: a fuzzy approach. Automation in Construction, 29(1), 123-135. https://doi.org/10.1016/j.autcon.2012.09.007

Li, T. H. Y., Ng, S. T., \& Skitmore, M. (2012). Public participation in infrastructure and construction projects in china: from an EIA-based to a whole-cycle process. Habitat International, 36(1), 47-56. https://doi.org/10.1016/j.habitatint.2011.05.006

Liu, J., \& Lin, B. (2012). Government auditing and corruption control: evidence from China's provincial panel data. China Journal of Accounting Research, 5(2), 163-186. https://doi.org/10.1016/j.cjar.2012.01.002

Liu, T., Wang, Y., \& Wilkinson, S. (2016). Identifying critical factors affecting the effectiveness and efficiency of tendering processes in public-private partnerships (PPPs): a comparative analysis of Australia and China. International Journal of Project Management, 34(4), 701-716.

https://doi.org/10.1016/j.ijproman.2016.01.004

Martimort, D., \& Straub, S. (2009). Infrastructure privatization and changes in corruption patterns: the roots of public discontent. Journal of Development Economics, 90(1), 69-84. https://doi.org/10.1016/j.jdeveco.2008.08.002

Moszoro, M. (2014). Efficient public-private capital structures. Annals of Public \& Cooperative Economics, 85(1), 103-126. https://doi.org/10.1111/apce.12028

Munnell, A. H., \& Cook, L. M. (1990). How does public infrastructure affect regional economic performance. New England Economic Review, 5, 11-32.

Ng, S. T., Wong, J. M. W., \& Wong, K. K. W. (2013). A public private people partnerships (P4) process framework for infrastructure development in Hong Kong. Cities, 31(2), 370-381. https://doi.org/10.1016/j.cities.2012.12.002

Ng, S. T., Wong, Y. M. W., \& Wong, J. M. W. (2012). Factors influencing the success of PPP at feasibility stage-a tripartite comparison study in Hong Kong. Habitat International, 36(4), 423-432. https://doi.org/10.1016/j.habitatint.2012.02.002

Osei-Kyei, R., \& Chan, A. P. C. (2015). Review of studies on the critical success factors for public-private partnership (PPP) projects from 1990 to 2013. International Journal of Project Management, 33(6), 1335-1346.

https://doi.org/10.1016/j.ijproman.2015.02.008
Osei-Kyei, R., \& Chan, A. P. C. (2018a). Stakeholder's perspectives on the success criteria for public-private partnership projects. International Journal of Strategic Property Management, 22(2), 131-142. https://doi.org/10.3846/ijspm.2018.444

Osei-Kyei, R., \& Chan, A. P. C. (2018b). Comparative study of governments' reasons/motivations for adopting public-private partnership policy in developing and developed economics/ countries. International Journal of Strategic Property Management, 22(5), 403-414. https://doi.org/10.3846/ijspm.2018.5223

Osei-Kyei, R., Chan, A. P. C., Javed, A. A., \& Ameyaw, E. E. (2017). Critical success criteria for public-private partnership projects: international experts' opinion. International Journal of Strategic Property Management, 21(1), 87-100. https://doi.org/10.3846/1648715X.2016.1246388

Sengupta, U. (2006). Government intervention and public-private partnerships in housing delivery in Kolkata. Habitat International, 30(3), 448-461. https://doi.org/10.1016/j.habitatint.2004.12.002

Shrestha, A., Chan, T. K., Aibinu, A. A., Chen, C., \& Martek, I. (2017). Risks in PPP water projects in china: perspective of local governments. Journal of Construction Engineering and Management, 143(7), 1-12.

https://doi.org/10.1061/(ASCE)CO.1943-7862.0001313

Su, C., Mitchell, R. K., \& Sirgy, M. J. (2007). Enabling guanxi management in China: a hierarchical stakeholder model of effective guanxi. Journal of Business Ethics, 71(3), 301-319. https://doi.org/10.1007/s10551-006-9140-3

Tang, Q. Q., Zhen, L. M., \& Yi-Dong, L. I. (2008). The infrastructure investment efficiency of public capital and private capital. Journal of Business Economics, 1(12), 34-41.

Tserng, H. P., Russell, J. S., Hsu C. W., \& Lin, C. (2012). Analyzing the role of national PPP units in promoting PPPs: using new institutional economics and a case study. Journal of Construction Engineering and Management, 138(2), 242-249. https://doi.org/10.1061/(ASCE)CO.1943-7862.0000398

Van Rijckeghem, C., \& Weder, B. (2001). Bureaucratic corruption and the rate of temptation: do wages in the civil service affect corruption, and by how much? Journal of Development Economics, 65(2), 307-331.

https://doi.org/10.1016/S0304-3878(01)00139-0

Vitner, G., Rozenes, S., \& Spraggett, S. (2006). Using data envelope analysis to compare project efficiency in a multi-project environment. International Journal of Project Management, 24(4), 323-329. https://doi.org/10.1016/j.ijproman.2005.09.004

Wang, Y., Cui, P., \& Liu, J. (2018). Analysis of the risk-sharing ratio in PPP projects based on government minimum revenue guarantees. International Journal of Project Management, 36(6), 899-909. https://doi.org/10.1016/j.ijproman.2018.01.007

Wanke, P. F. (2013). Physical infrastructure and flight consolidation efficiency drivers in Brazilian airports: a two-stage network-DEA approach. Transport Policy, 29(7), 145-153. https://doi.org/10.1016/j.tranpol.2013.05.004

Wibowo, A. (2004). Valuing guarantees in a BOT infrastructure project. Engineering Construction \& Architectural Management, 11(6), 395-403. https://doi.org/10.1108/09699980410571543

Wibowo, A., Permana, A., Kochendörfer, B., Kiong, R. T. L., Jacob, D., \& Neunzehn, D. (2012). Modeling contingent liabilities arising from government guarantees in Indonesian BOT/PPP toll roads. Journal of Construction Engineering and Management, 138(12), 1403-1410.

https://doi.org/10.1061/(ASCE)CO.1943-7862.0000555

$\mathrm{Xu}, \mathrm{Y}$., \& Yeh, C. H. (2014). A performance-based approach to project assignment and performance evaluation. International Journal of Project Management, 32(2), 218-228. https://doi.org/10.1016/j.ijproman.2013.04.006 
Xu, Y., Lu, Y., Chan, A. P., Skibniewski, M. J., \& Yeung, J. F. (2012). A computerized risk evaluation model for publicprivate partnership (PPP) projects and its application. International Journal of Strategic Property Management, 16(3), 277-297. https://doi.org/10.3846/1648715X.2012.686928

Xu, Y., Yeung, J. F. Y., Chan, A. P. C., Chan, D. W. M., Wang, S. Q., \& Ke, Y. (2010). Developing a risk assessment model for PPP projects in China - a fuzzy synthetic evaluation approach. Automation in Construction, 19(7), 929-943. https://doi.org/10.1016/j.autcon.2010.06.006

Yao, C. (2009). Additive efficiency decomposition in two-stage DEA. European Journal of Operational Research, 196(3), 11701176. https://doi.org/10.1016/j.ejor.2008.05.011

Zhang, S., Chan, A. P. C., Feng, Y., Duan, H., \& Ke, Y. (2016). Critical review on PPP research - a search from the Chinese and international journals. International Journal of Project Management, 34(4), 597-612.

https://doi.org/10.1016/j.ijproman.2016.02.008
Zhang, S., Gao, Y., Feng, Z., \& Sun, W. (2015). PPP application in infrastructure development in China: institutional analysis and implications. International Journal of Project Management, 33(3), 497-509.

https://doi.org/10.1016/j.ijproman.2014.06.006

Zhang, Y. (2014). From state to market: private participation in China's urban infrastructure sectors, 1992-2008. World Development 64 , 473-486.

https://doi.org/10.1016/j.worlddev.2014.06.023

Zhang, J., Gao, Y., Fu, Y., \& Zhang, H. (2007). Why does China enjoy so much better physical infrastructure? Economic Research Journal, 3, 4-19.

Zhu, J. (2000). Multi-factor performance measure model with an application to fortune 500 companies. European Journal of Operational Research, 123(1), 105-124. https://doi.org/10.1016/S0377-2217(99)00096-X

Zhu, J. (2011). Airlines performance via two-stage network DEA approach. Journal of Centrum Cathedra, 4(2), 260-269. https://doi.org/10.7835/jcc-berj-2011-0063 